УДК 374.7; 351.851; 346.232

DOI: https://doi.org/10.35387/od.1(19).2021.19-36

Аніменко Олена Валерї̈вна -
доктор педагогічних наук,
профресор, завідувач відділу
андрагогіки
педагогічної освіти Інституту
дорослих імені Івана Зязюна
НАПН України

Anishchenko Olena - Doctor of Pedagogical Sciences, Professor, Head of the Department of Andragogy of the Ivan Ziaziun Institute of Pedagogical and Adult Education of the NAES of Ukraine

ORCID iD: http://orcid.org/0000-0002-6145-2321

E-mail: anishchenko_olena@ukr.net

\title{
ОСВІТА ДОРОСЛИХ У РЕГІОНАЛЬНИХ ДОКУМЕНТАХ СТРАТЕГІЧНОГО ПЛАНУВАННЯ: НА ШЛЯХУ ДО СТАЛОГО РОЗВИТКУ СУСПІЛЬСТВА В УКРАЇНІ
}

Анотація. Автором проаналізовано окремі особливості розвитку освіти дорослих в Украӥні у контексті Цілей сталого розвитку (ЦСР). Підкреслено, що у ЦСР зокрема йдеться освіту дорослих, що підтверджує важливість розвитку цієї сфрери. Виявлено, що окрім національних стратегічних документів з розвитку загальної середньої, вищої, фрахової передвищої, професійної (профресійно-технічної) освіти, в Україні розробляються й ті, що безпосередньо стосуються розвитку освіти дорослих в окремих регіонах, населених пунктах. Підкреслено, що поява в Україні комплексних стратегічних документів щодо розвитку освіти дорослих у регіонах, а також тематичні блоки щодо розвитку освіти дорослих в окремих сучасних стратегічних документах регіонального рівня є иілком логічним і закономірним явищем. Здійснено аналіз окремих регіональних документів стратегічного планування (стратегій, програм, планів тощо), в яких унаочнено різні аспекти розвитку освіти дорослих як складової освіти впродовж життя. Обгрунтовано, що такі документи відіграють важливу роль у розвитку формальної $і$ неформальної освіті дорослих, сприяють розбудові суспільства, що навчається, у різних регіонах в Україні. Вони $\epsilon$ інструментами посилення конкурентоспроможності громадян, окремих громад і регіонів, держави в цілому.

Наголошено на важливості партнерства закладів освіти, наукових установ, громадських організацій, бізнесу, органів місцевої влади тощо задля успішності розвитку освіти дорослих. Приділено увагу ухваленим упродовж 2018 - 2020 рр. меморандумам про взаєморозуміння, партнерство у сфрері освіти дорослих - документам, що сприяють визнанню на регіональному рівні важливості ціложиттєвого навчання, а також узгодженню та координації зусиль стейкхолдерів у иій сфрері (Мелітополь, Суми, Вінниця).

Ключові слова: освіта дорослих; освіта впродовж життя; Цілі 
сталого розвитку; сталий розвиток суспільства; стратегічне планування; регіональний розвиток; Україна.

Anishchenko Olena

\section{ADULT EDUCATION IN THE REGIONAL DOCUMENTS OF STRATEGIC PLANNING: ON THE WAY TO SUSTAINABLE SOCIETY DEVELOPMENT IN UKRAINE}

Abstract. The author analyzes some peculiarities of adult education development in Ukraine in the context of the Sustainable Development Goals (SDGs). It is emphasized that the SDGs, in particular, deals with adult education, which confirms the importance of this area development. It was found that in addition to national strategic documents for the development of general secondary, higher, professional under-higher, vocational (technical) education, in Ukraine it is developing those that directly relate to the development of adult education in certain regions and settlements. There has been noted that the appearance in Ukraine of comprehensive strategic documents on the development of adult education in the regions, as well as thematic blocks on the development of adult education in some modern strategic documents at the regional level is a logical and natural phenomenon. The analysis of individual regional documents of strategic planning (strategies, programs, plans, etc.), which identified various aspects of adult education as a component of lifelong learning, was carried out. It is substantiated that such documents play an important role in the development of formal and non-formal adult education, contribute to the development of the learning society in different regions of Ukraine. They are tools to improve the competitiveness of citizens, individual communities and regions, and the state as a whole.

The importance of partnership of educational institutions, research institutions, public organizations, business, local authorities, etc. for the success of adult education is emphasized in the article. The prognostic substantiation of the further one is carried out. Attention is paid to the adopted during 2018-2020 memoranda on understanding and partnership in the field of adult education documents that promote recognition at the regional level of the importance of lifelong learning, as well as adjustment and coordination of stakeholders' efforts in this area (Melitopol, Sumy, Vinnytsia).

Key words: adult education; lifelong learning; Sustainable Development Goals; sustainable development of society; strategic planning; regional development; Ukraine.

Постановка проблеми, її актуальність. Розвиток освіти і науки $€$ важливою умовою досягнення сталого (збалансованого) розвитку суспільства, ефрективного управління, обґрунтованого прийняття рішень, зміцнення громадянського суспільства, демократії. Рівень освіченості разом із показниками добробуту, тривалості життя є складовою індексу людського розвитку (Human Development Index, HDI) - інтегрального рейтингового показника, що характеризує ступінь задоволення потреб людини та рівень 
забезпечення іï прав (Позняк, 2006). Щодо людського розвитку слід зазначити, що освіта в цілому позитивно впливає на різні сторони життєдіяльності людини, ії̈ соціальну активність, розширює доступ до знань, сприяє розвитку вмінь користуватися ними у сфрері професіійної самореалізації, повсякденному житті тощо, а власне «освічена людина більш ефрективно використовує свої здібності, ффізичний та природний капітал, завдяки чому він стає більш продуктивним» (Садовенко, Масловська \& Середа, 2011, с. 167-168). Отже, йдеться про суттєве розширення можливостей людини упродовж усього життя.

Не викликає сумнівів те, що людина $є$ джерелом i водночас головним рушієм розвитку суспільства. Ціннісне ставлення до людини, створення умов для її особистісно-професійного зростання, реалізації інтелектуального, творчого потенціалу, підтримка й сприяння розвитку формальної, нефрормальної та інформальної освіти становлять фрундамент сталого розвитку суспільства. Як відомо, 17 глобальних Цілей сталого розвитку (далі - ЦСР) унаочнено у підсумковому документі «Перетворення нашого світу: порядок денний у сфері сталого розвитку до 2030 року» (Саміт $\mathrm{OOH}$ зі сталого розвитку (вересень 2015 р., Нью-Йорк) (Transforming our world: the 2030 Agenda for Sustainable Development, 2015). Вони сфокусовані на трьох вимірах сталого розвитку: економічному, соціальному та екологічному. Україна, як й інші країни - члени ООН, приєдналася до глобального процесу забезпечення сталого розвитку. Упродовж 2016-2017 pp. тривав широкомасштабний, всеосяжний процес адаптації Цілей сталого розвитку з урахуванням українського контексту. Кожну глобальну ціль було переглянуто з урахуванням специфріки національного розвитку (Цілі сталого розвитку та Україна, 2019).

Аналіз останніх досліджень і публікацій. Загальнотеоретичні й практичні питання сталого розвитку висвітлено у працях українських науковців, серед яких - О. Білорус, І. Бистряков, В. Боголюбов, В. Геєць, Л. Жарова, Т. Кожухова, М. Клименко, О. Кулініч, В. Куценко, С. Лісовський, Д. Лук'яненко, О. Мартюшева, Г. Марушевський, Ю. Мацейко, Л. Мельник, В. Новицький, Я. Остафійчук, О. Ракоїд, Е. Лібанова, Л. Руденко, Т. Тимочко, В. Удовиченко, М. Хвесик та ін. Соціальний потенціал сталого розвитку досліджують О. Амоша, В. Антонюк, В. Бібікова, О. Вишневський, О. Воловодова, С. Гріневська, М. Дейч, Ю. Залознова, О. Іщенко, О. Касперович, М. Кримова, Д. Кузнєцова, С. Кучін, Л. Логачова, О. Новікова, А. Панькова, О. Панькова, О. Прогнімак, О. Сидорчук, Н. Стежко, Л. Шамілева, Л. Шаульська та ін. Проблема сталого розвитку у сфрері культури стала предметом наукових пошуків Н. Драгомирецької, С. Дружиніна, С. Думинської, Р. Жилавської, Ю. Ковальової та ін. Питання розбудови освіти для сталого розвитку візуалізовано у науковому, методичному доробку О. Висоцької, М. Завгородньої, Т. Іванової, І. Карпань, В. Кириленко, І. Кореневої, О. Маслюківської, В. Підліснюк, О. Пометун, Т. Сергієнко, М. Скрипник, А. Шаховської, М. Шелудько та ін. Напрацювання зазначених вище й багатьох інших дослідників $€$ підґрунтям розроблення науково-методичних засад і практичного інструментарію освітньої політики 
задля сталого розвитку регіонів, що навчаються. Водночас, незважаючи на значну кількість різноаспектних джерел щодо сталого розвитку, аналіз поступу освіти дорослих, візуалізованого у регіональних документах стратегічного планування у контексті сталого розвитку суспільства в Україні, не став предметом цілісних досліджень й потребує посиленої уваги науковців.

Мета статті - на основі вивчення регіональних документів стратегічного планування здійснити аналіз поступу освіти дорослих у контексті сталого розвитку суспільства в Україні.

Виклад основного матеріалу дослідження. Як відомо, шляхом адаптації ЦСР для України з урахуванням специфіки національного розвитку унормовано систему ЦСР, яка складається із 86 завдань із 183 показниками для моніторингу (Цілі сталого розвитку. Україна, 2020, с. 6). Відповідно до глобального «Порядку денного в галузі сталого розвитку на період до 2030 року» навчання дорослих сприяє досягненню всіх 17 Цілей сталого розвитку, спрямованих на забезпечення позитивних зрушень у соціальній, політичній, економічній, екологічній та культурній сферах, і майже кожна з 17 ЦСР передбачає реалізацію завдання або принаймні одного заходу, пов'язаного 3 навчанням, освітою або питаннями посилення обізнаності щодо освіти (Цілі сталого розвитку в Україні; Manifesto for Adult Learning in the 21st century ... 2019, p. 19; The SDGS in action).

Важливо підкреслити, що, зокрема, відповідно до ЦСР 4 «Якісна освіта» передбачено забезпечення всеохопної освіти - інклюзивної та якісної освіти на рівноправній основі для всіх, заохочення навчання впродовж всього життя для всіх (Цілі сталого розвитку. Україна, 2020). Так, у ЦСР 4 виокремлено завдання 4.3: забезпечити доступність професійної освіти; завдання 4.4: підвищити якість вищої освіти та забезпечити її тісний зв'язок 3 наукою, сприяти формуванню в країні міст освіти та науки; завдання 4.5: збільшити поширеність серед населення знань і навичок, необхідних для отримання гідної роботи та підприємницької діяльності (серед індикаторів індикатор 4.5.1: рівень участі населення у формальних і неформальних видах навчання та професійної підготовки).

Викладене вище свідчить про те, що у ЦСР зокрема йдеться освіту дорослих, що посилює важливість розвитку й підтримки цієї сфери. Освіта дорослих і навчання впродовж усього життя $€$ й наскрізною метою, й одним із інструментів досягнення ЦСР (Manifesto for Adult Learning in the 21st century ... 2019, p. 19; The SDGS in action). Нагадаємо, що власне освіта для сталого розвитку ґрунтується на припущенні про те, що людство має радикально змінити сучасний поступ економічного, екологічного й соціального розвитку для забезпечення здорового та якісного життя нинішніх і прийдешніх поколінь.

У контексті порушеної проблеми вважаємо за доцільне акцентувати увагу на тому, що необхідність забезпечення конкурентоспроможності громад і територій актуалізує важливість розроблення та впровадження регіональних, місцевих програм, стратегій, стратегічних планів розвитку громад, в яких відображено стан і перспективні напрями їх розвитку. В ідеалі, 
такі документи $€$ інструментами покращення конкурентоспроможності громадян, окремих громад і регіонів, держави в цілому, сприяють розвитку суспільства, що навчається тощо. Програмні документи (зокрема, стратегії розвитку об'єднаних територіальних громад тощо) визначають пріоритети та напрями розвитку громад і регіонів на найближчі роки. Підкреслимо, що у них передбачені розділи, сфокусовані на людському, трудовому потенціалі. У контексті зазначеного вище пропонуємо вибірково деталізувати окремі фрагменти деяких документів.

До прикладу, у стратегії Пирятинської ОТГ на 2017-2020рр. (Стратегія розвитку Пирятинської міської об’єднаної територіальної громади, 2017 , с. 29) у стратегічній цілі С. «Створення свідомої та активної громади 3 високою якістю життя» у рамках оперативної цілі С. 1 «Удосконалення системи комунікації з громадою» виокремлено проєкт С. 1.2 «Створення системи навчання та перенавчання дорослих», що передбачає підвищення фінансової грамотності малозабезпечених і соціально вразливих груп населення.

В іншому документі - «Стратегії розвитку Миколаївської області ...» (2020), зокрема, досягнення стратегічної цілі 2 «Висока якість життя людини» (п. 4.2) передбачається через реалізацію чотирьох оперативних цілей (ОЦ), серед яких виокремлено ОЦ 2.1: підготовка населення до життя та діяльності в умовах економіки, що змінюється. Зазначено, що пріоритетними напрямами освітньої діяльності в області $€$ надання всім громадянам рівних можливостей для здобуття якісної освіти, розвиток системи безперервної освіти та навчання впродовж життя тощо. У зазначеній Стратегії акцентовано увагу на тому, що у «системі освіти регіону вживаються заходи щодо забезпечення доступу до здобуття професійної освіти впродовж усього життя працюючому та незайнятому населенню, цілеспрямованого розвитку творчого потенціалу особистості та формування і підвищення професійних компетентностей; створюються умови для формальної, неформальної та інформальної освіти дорослих, модернізується система надання освітніх послуг ...» (Стратегія розвитку Миколаївської області, 2020, с. 72-73). Важливого значення набуває те, що «кількість створених центрів освіти дорослих / навчально-практичних центрів, од.» виокремлено як один із індикаторів для моніторингу виконання обґрунтованих у документі цілей (Стратегія розвитку Миколаївської області, 2020, с. 76).

Слід додати, що «Стратегія розвитку міста Мелітополя до 2030 року» (2019) містить стратегічну ціль «Формування сучасного інклюзивного культурного, освітнього та спортивного простору міста» (блок «Запровадження освіти упродовж життя»), «Стратегія розвитку міста Суми 2030» (2019) - стратегічну ціль «Створення можливостей для якісного життя, розвитку творчих здібностей та продуктивної роботи мешканців (блоки «Розвиток громадянської свідомості населення протягом життя», «Популяризація та розвиток освіти впродовж життя», «Престиж роботи педагогічного працівника»).

Розроблення регіональних документів стратегічного планування, що $€$ інструментами реалізації державної регіональної політики, здійснюється 3 
урахуванням стратегій розвитку міст, селищ і сіл, першочергового розвитку депресивних територій, стратегічних пріоритетів розвитку районів відповідного регіону (Берданова, Вакуленко, Валентюк \& Ткачук, 2017) відповідно до Конституції України, Законів України «Про місцеве самоврядування в Україні», «Про добровільне об'єднання територіальних громад», Указу Президента України «Про Стратегію сталого розвитку «Україна-2020», Постанов Кабінету Міністрів України «Про затвердження Державної стратегії регіонального розвитку до 2020 року», «Про затвердження Порядку розроблення регіональних стратегій розвитку і планів заходів з їх реалізації, а також проведення моніторингу та оцінки результативності реалізації зазначених регіональних стратегій і планів заходів», обласних і локальних стратегій регіонального розвитку на різні періоди, а також інших нормативно-правових актів України. Зазвичай вони гармонізовані з пріоритетами і цілями аналогічних документів вищого територіального (регіонального й національного) рівня (обласними стратегіями розвитку, Стратегією сталого розвитку «Україна-2020» тощо).

Документи стратегічного планування дозволяють проєктувати регіональний та/або місцевий розвиток як процес послідовних і стійких змін у місцевому середовищі, що сприяє позитивним змінам умов (укладу) життя територіальної громади, які можна оцінити об'єктивно - через систему соціально-економічних показників, а також суб'єктивно - через безпосереднє відчуття членами спільноти рівня особистого комфорту (Берданова, Вакуленко, Валентюк \& Ткачук, 2017), сприяють забезпеченню потреб роботодавців регіонів у кваліфікованих кадрах, розширенню можливостей зайнятості, професійної самореалізації та вдосконалення особистості упродовж життя відповідно до індивідуальних інтересів, потреб регіональної економіки тощо (Стратегічний план розвитку регіональної системи професійної (професійно-технічної) освіти, 2020).

Без сумніву, планування розвитку освіти дорослих у конкретному регіоні, населеному пункті $€$ складовою цілісної системи планування місцевого розвитку, розвитку об'єднаної територіальної громади. Стратегічні документи з розвитку освіти дорослих у регіонах являють собою науково обґрунтовані документи, в яких ураховано інтереси всіх цільових груп населення. Їх розроблення здійснюється на основі залучення широкого кола різних партнерів із державного, комерційного, громадського секторів суспільства. Йдеться про залучення експертів - представників органів місцевого самоврядування, бізнес-середовища, науки, освіти, культури, громадських організацій (загальнонаціональних, регіональних), засобів масової інформації, роботодавців, закладів соціальної допомоги, охорони здоров'я, комунальних підприємств - агентств (агенцій) розвитку міських рад, розробників документів стратегічного планування та ін. У процесі розроблення регіональних документів стратегічного планування у сфері освіти, окрім загальних принципів стратегічного планування, доцільно враховувати й такі: відповідальність, чутливість до потреб громади, залучення широкого кола стейкхолдерів, розвиток спроможності, навчання в дії (Мархлєвскі \& Процак, 2018, с. 12). За таких умов стратегічні документи 3 
розвитку освіти дорослих набудуть більшої затребуваності у регіонах.

Як відомо, доктрини, концепції, стратегії, програми, проєкти, плани розвитку освіти тощо $є$ документами, що унаочнюють перспективність, прогностичність бачення розвитку освітньої галузі країни, можливості ресурсів для його забезпечення, політики, спрямованої на використання цих ресурсів та обумовлюють відповідні напрями діяльності органів державної влади. Важливого значення набуває те, що в Україні, окрім керівних документів державної політики у сфері загальної середньої, вищої, фахової передвищої, професійної (професійно-технічної) освіти, розробляються й ті, що безпосередньо стосуються розвитку освіти дорослих в окремих регіонах, населених пунктах. На наше переконання, особливої уваги заслуговують саме регіональні документи стратегічного розвитку у сфері освіти, в яких візуалізовано різні аспекти освіти дорослих як складової освіти впродовж життя (Аніщенко, 2020).

У процесі дослідницького пошуку нами було виявлено та проаналізовано 8 документів стратегічного планування регіонального рівня у сорері освіти дорослих. Перелік цих документів, розроблених та уведених у дію в Україні упродовж 2014 - 2021 рр., відображено у таблиці 1 (у хронологічному порядку).

Таблиця 1

\section{Освіта дорослих в Україні: регіональні документи стратегічного планування (2014 - 2021 рр.)}

\begin{tabular}{|c|c|c|}
\hline Назва документу & $\begin{array}{l}\text { Дата затверд- } \\
\text { ження }\end{array}$ & $\begin{array}{l}\text { Географія } \\
\text { впроваджен- } \\
\text { ня }\end{array}$ \\
\hline \multicolumn{3}{|c|}{ Стратеаії розвитку освіти дорослих } \\
\hline $\begin{array}{l}\text { Стратегія розвитку навчання дорослих } \\
\text { у Яворівському районі на } 2014-2020 \text { рр. }\end{array}$ & $2014 \mathrm{p}$. & $\begin{array}{l}\text { Яворівський } \\
\text { р-н, Львівська } \\
\text { обл. }\end{array}$ \\
\hline $\begin{array}{l}\text { Стратегія розвитку сільських центрів освіти } \\
\text { дорослих у Сколівському районі Львівської } \\
\text { обл. }{ }^{*}\end{array}$ & $\begin{array}{l}2014 \text { р.* } \\
\text { * Примітка: } \\
\text { документ не } \\
\text { набув офіційного } \\
\text { статусу. }\end{array}$ & $\begin{array}{l}\text { Сколівський } \\
\text { р-н, Львівська } \\
\text { обл. }\end{array}$ \\
\hline \multicolumn{3}{|c|}{ Програми, плани розвитку освіти дорослих (міських і сільських громад) } \\
\hline $\begin{array}{l}\text { Освіта дорослих в м. Нікополі на 2019-2021 } \\
\text { роки (міська програма) }\end{array}$ & 2018 p. & $\begin{array}{l}\text { Нікопольська } \\
\text { міська } \\
\text { громада, } \\
\text { Дніпропет- } \\
\text { ровська обл. }\end{array}$ \\
\hline $\begin{array}{l}\text { Програма неформальної освіти дорослих } \\
\text { на базі Централізованої бібліотечної } \\
\text { системи для дорослих м. Львова }\end{array}$ & 2020 p. & $\begin{array}{l}\text { Львівська } \\
\text { міська } \\
\text { громада, }\end{array}$ \\
\hline
\end{tabular}




\begin{tabular}{|c|c|c|}
\hline & & Львівська обл. \\
\hline $\begin{array}{l}\text { План дій із удосконалення послуг щодо } \\
\text { освіти дорослих на території Галицинівської } \\
\text { сільської ради (ОТГ) на 2020-2026 роки }\end{array}$ & 2020 p. & $\begin{array}{l}\text { Галицинівська } \\
\text { ОТГ, } \\
\text { Миколаївська } \\
\text { обл. }\end{array}$ \\
\hline $\begin{array}{l}\text { Розвиток освіти дорослих в м. Мелітополі } \\
\text { Запорізької області на 2021-2025 роки } \\
\text { (комплексна міська програма) }\end{array}$ & 2021 p. & $\begin{array}{l}\text { Мелітопольсь- } \\
\text { ка міська } \\
\text { громада, } \\
\text { Запорізька } \\
\text { обл. }\end{array}$ \\
\hline $\begin{array}{l}\text { Вінниця - громада відкритих можливостей } \\
\text { для людей похилого віку Вінницької міської } \\
\text { територіальної громади на 2021-2023 роки } \\
\text { (міська програма) }\end{array}$ & $2021 \mathrm{p}$. & $\begin{array}{l}\text { Вінницька } \\
\text { міська } \\
\text { громада, } \\
\text { Вінницька обл. }\end{array}$ \\
\hline $\begin{array}{l}\text { Розвиток освіти дорослих у Полтавській } \\
\text { міській територіальній громаді на } 2021 \text { - } \\
2025 \text { роки (цільова програма) }\end{array}$ & 2021 p. & $\begin{array}{l}\text { Полтавська } \\
\text { міська } \\
\text { громада, } \\
\text { Полтавська } \\
\text { обл. }\end{array}$ \\
\hline
\end{tabular}
лimepamypu

Джерело: складено автором на основі опрацювання використаної

Як випливає з таблиці 1, лідерські позиції посідає Львівщина (розроблено три документи, з яких уведено в дію два), по одному документу уведено в дію у Дніпропетровській, Вінницькій, Миколаївській, Запорізькій, Полтавській областях. Сім документів затверджено офіційними рішеннями міських і селищних рад. Водночас Сколівська стратегія, як зазначають її розробники, пройшла попереднє обговорення на засіданні Погоджувальної ради Сколівської міської ради, але, на жаль, не набула офіційного статусу через низку бюрократичних та інших фракторів. Зазначені вище документи розроблено за сприяння Представництва DVV International в Україні (Інституту 3 міжнародного співробітництва німецької асоціації народних університетів DVV International).

Серед перших регіональних документів стратегічного планування, розроблених у нашій державі й сфокусованих на розвитку освіти дорослих, доцільно виокремити оприлюднену й затверджену 2014 р. на сесії районної радu «Стратегію розвитку навчання дорослих у Яворівському районі на 2014 - 2020 рр.» (Львівська обл.). Документ було розроблено та впроваджено у рамках проєкту «Освіта дорослих для розвитку: Створення мережі центрів Освіти Дорослих у Яворівському районі Львівської області на базі бібліотек і будинків культури», зреалізованого ГО ТКЯ «Гостинець» у партнерстві 3 Західноукраїнським ресурсним центром, відділом культури Яворівської райдержадміністрації, районної ради за фрінансової підтримки Представництва DVV International в Україні (Косик, 2017). На основі аналізу історичного досвіду освіти дорослих у документі акцентовано увагу на необхідності сприяння розвитку бібліотек - фрілій, Народних домів - центрів навчання дорослих, розвитку інформаційного, науково-технічного, 
економічного й культурного потенціалу Яворівщини тощо.

Зазначимо, що з-поміж пріоритетних завдань упровадження Стратегії її розробники виокремили такі: створення мережі центрів освіти дорослих у Яворівському районі; освіта дорослих спрямовується на оволодіння загальнолюдськими цінностями, налагодження взаємозв'язків між ринком освітніх послуг і ринком праці, створення необхідних умов для всебічного розвитку особистості, реалізації власних потенційних можливостей, що сприяє як її адаптації до динамічних соціально-економічних змін, так і соціальній захищеності; удосконалення компетентностей, «набутих людиною до входження у сферу оплачуваної трудової діяльності, що забезпечуються системою установ і освітніх програм, спрямованих на здобуття нових компетентностей і подальше їхнє збагачення»; створення освітнього, інформаційно-комунікаційного простору освіти дорослих; систематизація навчально-методичних видань на електронних та паперових носіях; підготовка веб-сторінок, блогів, просвітницьких бюлетенів бібліотек; участь у регіональних і міжнародних проєктах (Стратегія розвитку навчання дорослих у Яворівському районі, 2014). Розробниками цитованого документу обґрунтовано доцільність здійснення моніторингових досліджень з метою «збору й аналізу результатів анкетування, здійснення альтернативних заходів, діагностика стану й тенденцій розвитку ЦНД, розробки нових рекомендацій ...», окреслено коло провайдерів у сфері освіти дорослих району, перспективи розвитку освіти дорослих на Яворівщині (Стратегія розвитку навчання дорослих у Яворівському районі, 2014).

Уважаємо за доцільне зауважити, що з моменту затвердження цитованої Стратегії минуло майже 7 років. Отже, постає цілком закономірне питання: які ж здобутки має Яворівщина у сфері освіти дорослих? Стисло відповідаючи на це запитання передусім зазначимо, що місто Новояворівськ увійшло до Української мережі міст, що навчаються (Українська мережа міст, що навчаються), а також мережі ЮНЕСКО міст, що навчаються (Глобальна мережа міст ЮНЕСКО, що навчаються, 2021). В Яворівському районі функціонують 14 центрів освіти дорослих (далі - ЦОД), що реалізують освітні, культурно-просвітницькі проєкти, надають різноманітні освітні послуги та спрямовують діяльність на збереження місцевих традицій. Відкрито також районний ЦОД на базі Новояворівського музею, що функціонує як координаційний і методичний центр для усіх чотирнадцяти ЦОД Яворівщини (Косик, 2017). Отже, Яворівщина $є$ одним із яскравих прикладів регіону, що навчається, який зреалізовує стратегію розвитку освіти дорослих.

В іншому документі - «Стратегії розвитку сільських центрів освіти дорослих у Сколівському районі Львівської обл.», передбачено створення мережі сільських Центрів освіти дорослих у районі задля:

- забезпечення відкритого доступу до інформації, ресурсів і інноваційних освітніх практик у галузі освіти дорослих на регіональному й національному рівнях;

- зміцнення організаційної та інституційної спроможність сільських ЦОД - членів мережі; 
- сприяння спільному плануванню, розробленню та впровадженню програм, інших освітніх ініціатив на місцевому та районному рівнях;

- поширення відповідної інформації, привернення уваги державних структур, суспільства в цілому до сільських ЦОД як інноваційних інституцій, що втілюють на практиці андрагогічні принципи навчання;

- сприяння сільським ЦОД, органам місцевого самоврядування, всім зацікавленим сторонам у прийнятті спільних виважених рішень і рекомендацій щодо розвитку освіти дорослих у Сколівському районі (Багрінець, 2015).

За задумом розробників стратегії, освіта дорослих $є$ «одним із головних ресурсів добробуту жителів Сколівського району та передумовою його економічного, соціального розвитку». Зреалізовані у районі якісні освітні програми відповідно до потреб різних категорій дорослих, незалежно від віку, рівня доходів та місця їх проживання, сприятимуть «економічній активності й зайнятості населення, врівноваженому та довгостроковому розвитку району, добробуту, демократизації суспільства, зростанню громадянської активності, духовності й самореалізації» (Багрінець, 2015).

Ми поділяємо думку авторів (Мархлєвскі \& Процак, 2018, с. 12) про те, що регіональні стратегії розвитку освіти унаочнюють підхід місцевої влади до виконання освітніх повноважень, віддзеркалюють «комплекс якісно сфрормульованих, публічно оголошених намірів і завдань, що ґрунтуються на суспільному консенсусі та впроваджуватимуться органами місцевого самоврядування», дозволяють «визначити сильні та слабкі сторони попередніх підходів та зосередитися на цілях і методах щодо майбутніх завдань». Також не викликають сумнівів умовиводи експертів (Strategies for improving participation in and awareness of adult learning, 2012, p. 13) про те, що регіональні, місцеві органи влади $\epsilon$ «найближчою» до громадян державною владою, що має значні потенційні можливості для ознайомлення, залучення дорослого населення до навчання, для комунікації та поширення інформації серед стейкхолдерів щодо освітніх послуг для різних категорій дорослих у громадах, що навчаються, розбудови мережевої взаємодії тощо.

Починаючи з 2019 р. в Україні активізувалося розроблення цільових та інших програм, сфокусованих на розвитку освіти дорослих у міських $i$ сільських територіальних громадах, а саме на:

- розвитку освіти дорослих з метою забезпечення поліпшення якості життєдіяльності нікопольчан, формування в місті культури навчання й забезпечення дорослому населенню вільного доступу до освіти упродовж життя тощо (Міська програма «Освіта дорослих в м. Нікополі на 2019 - 2021 роки», 2018; Smirnov \& Andrieiev, 2021, р. 230-231);

- створенні умов для безперервного навчання львів'ян шляхом посилення освітньої компоненти закладів культури, сприянні розвитку мережі центрів неформальної освіти дорослих на базі Централізованої бібліотечної системи для дорослих міста Львова тощо (Програма неформальної освіти дорослих на базі Централізованої бібліотечної системи для дорослих м. Львова, 2020);

$$
\text { - розширенні спектру надання послуг, пов'язаних із освітою }
$$


дорослих, та їх популяризації, що сприятиме розвитку освіти дорослого населення Галицинівської ОТГ, реалізації дорослими мешканцями громади творчого й підприємницького потенціалу тощо (План дій із удосконалення послуг щодо освіти дорослих на території Галицинівської сільської ради (ОТГ) на 2020-2026 роки, 2020);

- створенні сприятливих умов для розвитку людського потенціалу жителів Мелітополя, їх професійного та особистісного розвитку, сприянні соціальній згуртованості, міжкультурному діалогу, зменшенню соціальної ізоляції дорослого населення шляхом володіння цифровими технологіями, розвитку критичного мислення та розширення прав і можливостей громадян, зміцненню громадянського суспільства тощо (Комплексна міська програма «Розвиток освіти дорослих в місті Мелітополі на 2021-2025 роки, 2021);

- залученні вінничан старшого віку до участі в освітніх процесах, формуванні політики навчання упродовж життя задля розширення можливостей з посилення соціального потенціалу та активізації участі людей похилого віку в житті Вінницької міської територіальної громади тощо (Програма «Громада відкритих можливостей для людей похилого віку Вінницької міської територіальної громади на 2021-2023 роки», 2021);

- створенні умов для розвитку освіти дорослих на засадах комплексного розуміння її суспільної цінності та значущості, проведенні маркетингових і соціологічних досліджень для визначення громадської думки, запитів і потреб жителів Полтавської міської ОТГ у сфері освіти дорослих, поширенні соціальної реклами щодо розвитку у громаді культури навчання впродовж життя, упровадженні освітніх програм для вразливих та інших категорій населення тощо (Цільова програма «Розвиток освіти дорослих у Полтавській міській територіальній громаді на 2021 - 2025 роки», 2021).

Вважаємо за доцільне додати, що у деяких стратегічних документах з розвитку освіти у регіонах виокремлено тематичні підрозділи, сфокусовані на окремих аспектах освіти дорослих: блок «Післядипломна педагогічна освіта» у «Програмі розвитку освіти Львівщини на 2017 - 2020 роки» (2017р.); блок «Підвищення кваліфікації педагогічних працівників» у розділі 3.1.18 «Освіта» («Програма економічного і соціального розвитку м. Слов'янська на 2019 рік та основні напрями розвитку на 2020 і 2021 роки» (2018); підпрограма «Підготовка фахівців, наукових, науковопедагогічних та робітничих кадрів, підвищення кваліфікації та перепідготовка кадрів за регіональним замовленням» (Міська комплексна цільова програма «Освіта Києва. 2019 - 2023 роки» (2018); розділ «Освітньо-інформаційний простір «Освіта дорослих» у «Програмі розвитку нової української освіти Галицинівської сільської ради Миколаївської області в умовах децентралізації на 2019-2021 роки» (2019) тощо.

Важливого значення також набуває те, що визнанню на регіональному рівні важливості ціложиттєвого навчання, а також узгодженню та координації зусиль стейкхолдерів у цій сфері сприяє укладання меморандумів про взаєморозуміння, партнерство у сфері освіти дорослих (м. Мелітополь (2018), м. Суми (2018), м. Вінниця (2020). Ці документи 
інфрормаційно-довідкового спрямування, зокрема, засвідчують партнерство міських рад, Представництва DVV International в Україні та громадських організацій, що здійснюють діяльність у сфері освіти дорослих. Водночас, як справедливо зазначають О. Смірнов, М. Андрєєв (Smirnov \& Andrieiev, 2021, р. 228), популяризація освіти впродовж усього життя, як і раніше, потребує державної підтримки як на загальнонаціональному, так і на регіональному, місцевому рівнях.

Принагідно зазначимо, що складно переоцінити важливість упровадження стратегічного підходу до сталого розвитку, який успішно застосовується у розвинених країнах світу. Як свідчить дослідження українських науковців (Марушевський, Руденко \& Тимочко, 2017), у таких країнах не тільки ухвалено національні стратегії сталого розвитку, а й періодично здійснюється їх перегляд. Щодо України, то у 2015 р. затверджено Стратегію сталого розвитку «Україна-2020», у 2017 р. розроблено проєкт «Стратегії сталого розвитку України до 2030 року». Водночас, на наше переконання, у нашій державі доцільно активізувати діяльність 3 розроблення та впровадження регіональних документів стратегічного планування у сфері освіти дорослих, а також здійснювати періодичне оновлення, перегляд відповідних документів, що набули чинності на різних етапах розвитку держави.

Висновки і перспективи подальших досліджень. Таким чином, регіональні документи стратегічного планування в освіті зазвичай відповідають пріоритетам державної регіональної політики щодо підвищення рівня конкурентоспроможності регіонів та ефективного управління у сфрері регіонального розвитку. Отже, цілком логічним і закономірним $є$ поява в Україні комплексних стратегічних документів з розвитку освіти дорослих у регіонах, а також те, що в окремих сучасних стратегічних документах регіонального рівня з'явилися тематичні блоки щодо розвитку освіти дорослого населення. Таку практику стратегічного планування на регіональному та місцевому рівнях як складову регіональної освітньої політики доцільно популяризувати, поширювати у всіх регіонах України.

Насамкінець зазначимо, що доцільність сприяння зміцненню засобів реалізації та активізації глобального партнерства задля сталого розвитку зафріксовано як тезу у ЦСР 17 «Партнерство задля досягнення Цілей». Без перебільшення можна стверджувати, що у сфері реалізації цілей сталого розвитку (зокрема, у сфрері освіти дорослих) винятково важливу роль відіграє партнерство органів державної влади, науки, освіти, бізнесу, інститутів громадянського суспільства тощо. Таке партнерство, а також упровадження зазначених вище та інших стратегічних документів, оновленої концепції розвитку освіти дорослих в Україні (Лук'янова, Аніщенко \& Москаленко, 2019), організаційно-розпорядчих документів (інструкцій, положень) щодо розвитку освіти дорослих у громадах для використання на місцевому рівні (розробник О. Пастушок) (Громадське обговорення ..., 2019) (ініціативи ГC «Українська асоціація освіти дорослих», Представництва DVV International в Україні) сприятимуть: розвитку громад і регіонів, що навчаються; профресіоналізації як освіти дорослих у цілому, так і 
педагогічного персоналу у цій сфері; розвитку мережевої взаємодії закладів освіти, наукових, освітніх, громадських та інших організацій, підприємств тощо для розвитку в дорослого населення культури навчання впродовж життя; мотивуванню різних категорій дорослих до особистісного й професійного зростання; забезпеченню реалізації індивідуальних освітніх траєкторій (маршрутів) дорослих впродовж усього життя; актуалізації, розробленню гнучких навчальних програм відповідно до освітньо-культурних запитів різних цільових категорій дорослих та їх упровадженню в умовах традиційного, дистанційного та змішаного навчання; розробленню механізмів незалежної оцінки й визнання результатів навчання, здобутих в умовах неформальної та інформальної освіти; створенню умов для розвитку корпоративного (внутрішньофрірмового) навчання, соціального підприємництва в освіті дорослих.

Перспективним напрямом подальщих наукових пошуків може стати вивчення зарубіжного досвіду стратегічного планування розвитку освіти дорослих у контексті регіональної освітньої політики.

\section{Список використаних джерел}

Багрінець, М. (2015). Про сільські Центри освіти дорослих на Львівщині. Територія успіху, 1 (1), 4-7.

Берданова, О.В., Вакуленко, В.М., Валентюк, І.В. \& Ткачук, А.Ф. (2017). Стратегічне планування розвитку об'єднаної територіальної громади: навч. посіб. Київ, 121.

Глобальна мережа міст ЮНЕСКО, що навчаються. (2021). URL: https://unesco.mfa.gov.ua/spivrobitnictvo/globalna-merezha-mistyunesko-shcho-navchayutsya

Громадське обговорення проектів документів у сфрері навчання та освіти дорослих. (2019). URL: http://www.uaod.org.ua/novini/zvernennya-do-mon-schodo-pidtrimkiosviti-doroslih-na-miscevomu-rivni/

Комплексна міська програма «Розвиток освіти дорослих в місті Мелітополі на 2021-2025 роки». (2021). Додаток до рішення 3 сесії Мелітопольської міської ради Запорізької області VIII скликання від 29.01.2021 № 5/1.

URL: https://mlt.gov.ua/uploads/documents/session/\%D0\%A0\%D0\%86\%D0\%A 8\%D0\%95\%D0\%9D\%D0\%9D\%D0\%AF\%2003_29.01.2021/8_5.1.doc.

Косик, Н. (2017). Велосипед вже винайдено - треба тільки навчитись їхати! Інтерв'ю записала ТПавліченко. Текст підготувала Ю. Голоднікова. URL: https://www.prostir.ua/?library=nataliya-kosykvelosyped-vzhe-vynajdeno-treba-tilky-navchytys-jihaty

Лук'янова, Л.Б., Аніщенко, О.В. \& Москаленко, Л.М. (2019). Концепція розвитку освіти дорослих в Україні. Проєкт. К.: ГС «Українська асоціація освіти дорослих»; ІПООД імені Івана Зязюна НАПН України.

Мархлєвскі, В. \& Процак, О. (2018). Стратегія розвитку освіти в громаді: практичний порадник. Київ, $56 \mathrm{c}$.

URL: 
https://storage.decentralization.gov.ua/uploads/library/file/186/strategy.pdf Марушевський, Г.Б., Руденко, Л.Г. \& Тимочко, Т.В. (2017). Майбутнє України - в реалізації стратегії сталого розвитку до 2030 року. Український географрічний журнал, 2, 32-34.

Міська програма «Освіта дорослих в м. Нікополі на 2019 - 2021 роки». (2018). Додаток до рішення міської ради 14.12.2018 р. № 29-43/VII. URL: http://www.nikopol-mrada.dp.gov.ua/publichna-informatsiia/miskitsilovi-prohramy/osvita-doroslykh-v-m-nikopoli-na-2019-2021-roky

План дій із удосконалення послуг щодо освіти дорослих на території Галицинівської сільської ради (ОТГ) на 2020-2026 роки. (2020). URL:

https://galycynivska.dosvit.org.ua/storage/documents/attachments/373 c30dce8abcf1c3bb97baebcc4e347.pdf

Позняк, О.В. (2006). Індекс людського розвитку. Енциклопедія Сучасної України: електронна версія [веб-сайт]. Гол. редкол.: І.М. Дзюба, А.І. Жуковський, М.Г. Железняк та ін.; НАН України, НТШ. Київ: ІЕД HAH України. URL: https://esu.com.ua/search_articles.php?id=13350

Програма «Громада відкритих можливостей для людей похилого віку Вінницької міської територіальної громади на 2021-2023 роки». (2021). Додаток до рішення Вінницької міської ради від 26.03.2021 № 310. URL: http://surl.li/aceyy

Програма неформальної освіти дорослих на базі Централізованої бібліотечної системи для дорослих м. Львова. (2020). Додаток до ухвали Львівської міської ради від 05.03.2020 р. № 6374. URL: https://www8.city-

adm.lviv.ua/inteam/uhvaly.nsf/(SearchForWeb)/110D78025B65DAF6C 225852900277081?OpenDocument

Садовенко, А., Масловська, Л., Середа, В. \& Т. Тимочко. (2011). Сталий розвиток суспільства: навчальний посібник. Вид. 2-е. Київ.

Стратегічний план розвитку регіональної системи професійної (професійно-технічної) освіти Запорізької області на 2021-2027 роки. (2020). Запоріжжя. URL: https://www.zoda.gov.ua/files/WP_Article_File/original/000151/151313.pdf

Стратегія розвитку Миколаївської області на період до 2027 року включно: рішення обласної ради 23 грудня 2020 року № 2. URL: https://www.minregion.gov.ua/wp-content/uploads/2021/02/strategiyarozvytku-mykolayivskoyi-oblasti-na-period-do-2027-roku.pdf

Стратегія розвитку міста Суми 2030. (2019). Додаток до рішення Сумської міської ради «Про затвердження Стратегії розвитку міста Суми до 2030 року» від 24 грудня 2019 року №6246 - MP. URL: https://smr.gov.ua/images/documents/Strategia/Strategia_Sumi_2030.pdf

Стратегія розвитку навчання дорослих у Яворівському районі на 2014 2020 рр. (2019). Додаток № 1 до рішення Яворівської районної ради від 05 грудня 2014 року № 505. URL: http://yavorivrajrada.org.ua/content/40-ses

Стратегія розвитку Пирятинської міської об'єднаної територіальної громади 
на 2017-2020 роки (2017). Пирятин: Б. м., б. в. URL: http://pyriatyn.org.ua/data/files/new/\%D0\%A1\%D0\%A2\%D0\%A0\%D0 $\% 90 \%$ D0\%A2\%D0\%95\%D0\%93.pdf

Цілі сталого розвитку. Україна. Добровільний національний огляд. (2020). Б. м. б. в., 2020. URL: https://cutt.ly/onvPa40

Цілі сталого розвитку та Україна. (2019). URL: https://www.kmu.gov.ua/diyalnist/cili-stalogo-rozvitku-ta-ukrayina

Цільова програма «Розвиток освіти дорослих у Полтавській міській територіальній громаді на 2021 - 2025 роки». (2021). Додаток 1 до рішення сесії Полтавської міської ради. URL: https://docs.google.com/document/d/1ihL9mTRYTVbvEw9LFNui5LebDZTmqFT/edit

Manifesto for Adult Learning in the 21st century: The Power and Joy of Learning. (2019). Gina Ebner and Ricarda Motschilnig (EAEA). Brussels: $\quad$ EAEA. URL: https://eaea.org/wpcontent/uploads/2019/04/eaea manifesto_final_web_version_290319.pdf

Smirnov, O. \& Andrieiev, M. (2021). Public financing of popular adult learning and education in Ukraine. Public Financing of Popular Adult Learning and Education (ALE). Bonn: DVV International. URL: https://www.dvvinternational.de/fileadmin/files/Inhalte_Bilder_und_Dokumente/Materiali en/Analysis/DVV_International_Analysis_Financing_Popular_ALE_Web2.pdf

Strategies for improving participation in and awareness of adult learning. (2012). European guide. Luxembourg: Publications Office of the European Union. DOI: 10.2766/26886 ; URL: https://www.ab.gov.tr/files/ardb/evt/1_avrupa_birligi/1_9_politikalar/1_9 4_egitim_politikasi/ec_guide_adult_learning.pdf

The SDGS in action. URL: https://www.undp.org/sustainable-developmentgoals

Transforming our world: the 2030 Agenda for Sustainable Development: A/RES/70/1. Resolution adopted by the General Assembly on 25 September 2015.

URL: https://www.un.org/ga/search/view_doc.asp?symbol=A/RES/70/1\&Lang=E

\section{References (translated and transliterated)}

Bahrinets', M. (2015). Pro sil's'ki Tsentry osvity doroslykh na L'vivshchyni [About rural adult education centers in Lviv region]. Terytoriia uspikhu - Territory of success, 1 (1), 4-7 [in Ukrainian].

Berdanova, O.V., Vakulenko, V.M., Valentyuk, I.V. \& Tkachuk, A.F. (2017). Stratehichne planuvannya rozvytku ob'yednanoyi terytorial'noyi hromady [Strategic planning for the development of a united territorial community]: navch. posib. Kyiv, 121 [in Ukrainian].

Hlobal'na merezha mist YUNESKO, shcho navchayut'sya [The UNESCO Global Network of Learning Cities]. (2021). URL: https://unesco.mfa.gov.ua/spivrobitnictvo/globalna-merezha-mist-yuneskoshcho-navchayutsya [in Ukrainian].

Hromads'ke obhovorennya proektiv dokumentiv u sferi navchannya ta osvity doroslykh [Public discussion of draft documents in the field of adult 
education]. (2019). URL: http://www.uaod.org.ua/novini/zvernennya-domon-schodo-pidtrimki-osviti-doroslih-na-miscevomu-rivni/ [in Ukrainian].

Kompleksna mis'ka prohrama «Rozvytok osvity doroslykh v misti Melitopoli na 2021 2025 roky» [Complex municipal program "Development of adult education in the city of Melitopol for 2021-2025»]. (2021). Dodatok do rishennya 3 sesiyi Melitopol's'koyi mis'koyi rady Zaporiz'koyi oblasti VIII sklykannya vid 29.01.2021

№ 5/1.

URL: https://mlt.gov.ua/uploads/documents/session/\%D0\%A0\%D0\%86\%D0\%A8 \%D0\%95\%D0\%9D\%D0\%9D\%D0\%AF\%2003_29.01.2021/8_5.1.doc.

Kosyk, N. (2017). Velosyped vzhe vynaideno - treba tilky navchytys yikhaty! [The bicycle has already been invented - you just have to learn to ride]. Interv'iu zapysala T. Pavlichenko. Tekst pidhotuvala Yu. Holodnikova. URL: https://www.prostir.ua/?library=nataliya-kosyk-velosyped-vzhe-vynajdenotreba-tilky-navchytys-jihaty

Luk'ianova, L.B., Anishchenko, O.V. \& Moskalenko, L.M. (2019). Kontseptsiia rozvytku osvity doroslykh $v$ Ukraini [Concept of the adult education development in Ukraine]. Proiekt. Kyiv: HS «Ukrainska asotsiatsiia osvity doroslykh»; IPOOD imeni Ivana Ziaziuna NAPN Ukrainy.

Markhlievski, V. \& Protsak, O. (2018). Stratehiia rozvytku osvity $v$ hromadi [Community education development strategy]: praktychnyi poradnyk. K., 56.

URL: https://storage.decentralization.gov.ua/uploads/library/file/186/strategy.pdf

Marushevskyi, H.B., Rudenko, L.H. \& Tymochko, T.V. (2017). Maibutnie Ukrainy - v realizatsii stratehii staloho rozvytku do 2030 roku [Future of Ukraine - in realization of strategy of steady development 2030]. Ukrainskyi heohrafichnyi zhurnal - Ukrainian Geographical Journal, 2, 32-34.

Miska prohrama "Osvita doroslykh v m. Nikopoli na 2019 - 2021 roky» [The municipal program «Adult Education in Nikopol for 2019 - 2021»]. (2018). Dodatok do rishennia miskoi rady 14.12.2018 r. № 29-43/VII. URL: http://www.nikopol-mrada.dp.gov.ua/publichna-informatsiia/miski-tsiloviprohramy/osvita-doroslykh-v-m-nikopoli-na-2019-2021-roky

Plan dii iz udoskonalennia posluh shchodo osvity doroslykh na terytorii Halytsynivskoi silskoi rady (OTH) na 2020-2026 roky [Action plan to improve adult education services in the territory of Halytsynivka village council (UTC) for 2020-2026]. (2020). URL: https://galycynivska.dosvit.org.ua/storage/documents/attachments/373c30d ce8abcf1c3bb97baebcc4e347.pdf

Pozniak, O.V. (2006). Indeks liudskoho rozvytku [Human Development Index]. Entsyklopediia Suchasnoi Ukrainy: elektronna versiia [veb-sait]. Hol. redkol.: I.M. Dziuba, A.I. Zhukovskyi, M.H. Zhelezniak ta in.; NAN Ukrainy, NTSh. Kyiv: IED NAN Ukrainy.

Prohrama «Hromada vidkrytykh mozhlyvostei dlia liudei pokhyloho viku Vinnytskoi miskoi terytorialnoi hromady na 2021-2023 roky» [The program «Community of Open Opportunities for the Elderly of the Vinnytsia Municipal Territorial Community for 2021-2023»]. (2021). Dodatok do rishennia Vinnytskoi miskoi rady vid 26.03.2021 № 310. URL: http://surl.li/aceyy

Prohrama neformalnoi osvity doroslykh na bazi Tsentralizovanoi bibliotechnoi systemy dlia doroslykh m. Lvova [Non-formal Adult Education Program 
based on the Centralized Library System for Adults in Lviv]. (2020). Dodatok do ukhvaly Lvivskoi miskoi rady vid 05.03.2020 r. № 6374. URL: https://www8.cityadm.Iviv.ua/inteam/uhvaly.nsf/(SearchForWeb)/110D78025B65DAF6C225 852900277081? OpenDocument

Sadovenko, A., Maslovska, L., Sereda, V. \& T. Tymochko. (2011). Stalyi rozvytok suspilstva [Sustainable development of society]: navchalnyi posibnyk. Vyd. 2-e. Kyiv.

Stratehichnyi plan rozvytku rehionalnoi systemy profesiinoi (profesiino-tekhnichnoi) osvity Zaporizkoi oblasti na 2021-2027 roky [Strategic plan for the development of the regional system of vocational (vocational) education of Zaporizhia region for 2021-2027]. (2020). Zaporizhzhia. URL: https://www.zoda.gov.ua/files/WP_Article_File/original/000151/151313.pdf

Stratehiya rozvytku Mykolaivskoi oblasti na period do 2027 roku vkliuchno [Development Strategy of the Mykolaiv region for the period 2021-2027]: rishennia oblasnoi rady 23 hrudnia 2020 roku № 2 . URL: https://www.minregion.gov.ua/wp-content/uploads/2021/02/strategiyarozvytku-mykolayivskoyi-oblasti-na-period-do-2027-roku.pdf

Stratehiya rozvytku mista Sumy 2030 [The Sumy city Development Strategy 2030]. (2019). Dodatok do rishennia Sumskoi miskoi rady vid 24 hrudnia 2019 roku №6246 - MR. URL: https://smr.gov.ua/images/documents/Strategia/Strategia_Sumi_2030.pdf

Stratehiya rozvytku navchannya doroslykh u Yavorivs'komu rayoni na 2014 2020 rr. [Strategy of development of adult learning in Yavoriv district for 2014 - 2020]. (2014). Dodatok № 1 do rishennya Yavorivs'koyi rayonnoyi rady vid 05 hrudnya 2014 roku № 505 . URL: http://yavorivrajrada.org.ua/content/40-ses

Stratehiya rozvytku Pyryatyns'koyi mis'koyi ob'yednanoyi terytorial'noyi hromady na 2017-2020 roky [Strategy of development of the Pyriatyn City municipal United Territorial Community for 2017-2020]. (2017). Pyryatyn: B. m., b. v. URL: http://pyriatyn.org.ua/data/files/

new/\%D0\%A1\%D0\%A2\%D0\%A0\%D0\%90\%D0\%A2\%D0\%95\%D0\%93.pdf

Tsili staloho rozvytku. Ukrayina. Dobrovil'nyy natsional'nyy ohlyad [Sustainable Development Goals: Ukraine. Voluntary National Review]. (2020). B. m., b. v. URL: https://cutt.ly/onvPa40

Tsili staloho rozvytku ta Ukrayina [Sustainable Development Goals and Ukraine]. (2019). URL: https://www.kmu.gov.ua/diyalnist/cili-stalogo-rozvitku-ta-ukrayina

Tsil'ova prohrama «Rozvytok osvity doroslykh u Poltavs'kiy mis'kiy terytorial'niy hromadi na 2021 - 2025 roky» [Target program «Development of adult education in the Poltava City municipal United Territorial Community for 2021 - 2025»]. (2021). Dodatok 1 do rishennya sesiyi Poltavs'koyi mis'koyi rady. URL: https://docs.google.com/document/d/1ihL9mTRYTVbvEw9LFNui5LebDZTmqFT/edit

Manifesto for Adult Learning in the 21st century: The Power and Joy of Learning. (2019). Gina Ebner and Ricarda Motschilnig (EAEA). Brussels: EAEA. URL: https://eaea.org/wpcontent/uploads/2019/04/eaea_manifesto_final_web_version_290319.pdf

Smirnov, O. \& Andrieiev, M. (2021). Public financing of popular adult learning and education in Ukraine. Public Financing of Popular Adult Learning and 
Education (ALE). Bonn: DVV. URL: https://www.dvvinternational.de/fileadmin/files/Inhalte_Bilder_und_Dokumente/Materialien/ Analysis/DVV_International_Analysis_Financing_Popular_ALE_Web2.pdf [in English].

Strategies for improving participation in and awareness of adult learning. (2012). European guide. Luxembourg: Publications Office of the European Union. DOI: $\quad 10.2766 / 26886 \quad ; \quad$ URL: https://www.ab.gov.tr/files/ardb/evt/1_avrupa_birligi/1_9_politikalar/1_9_4_ egitim_politikasi/ec_guide_adult_learning.pdf [in English].

The SDGS in action. URL: https://www.undp.org/sustainable-development-goals Transforming our world: the 2030 Agenda for Sustainable Development: A/RES/70/1. Resolution adopted by the General Assembly on 25 September 2015. URL: https://www.un.org/ga/ search/view_doc.asp?symbol=A/RES/70/1\&Lang=E [in English].

УДК 304.374

DOI: https://doi.org/10.35387/od.1(19).2021.36-51

Чаграк Наталія Іеорівна доктор педагогічних наук, дочент, профресор кафедри іноземних мов і країнознавства Прикарпатського національного університету імені Василя Стефраника
Chahrak Nataliya - Doctor of Science in Education, Associate Professor, Professor of the Department of Foreign Languages and Country Studies, Vasyl Stefanyk Precarpathian National University

ORCID iD: http://orcid.org/0000-0002-1583-2278

E-mail: natalya.chahrak@pnu.edu.ua

Жумбей Маріанна Михайлівна - кандидат педагогічних наук, доцент, доцент кафедри іноземних мов і країнознавства Прикарпатського національного університету імені Василя Стефраника
Zhumbei Marianna - Candidate of Pedagogical Sciences, Associate Professor, Associate Professor of the Department of Foreign Languages and Country Studies, Vasyl Stefanyk Precarpathian National University

ORCID iD: http://orcid.org/0000-0002-8883-4135

E-mail:marianna.zhumbei@pnu.edu.ua

\section{ПСИХОЛОГІЧНІ ЗАСАДИ НАВЧАЛЬНОЇ ДІЯЛЬНОСТІ ЛЮДЕЙ ТРЕТЬОГО ВІКУ}

Анотація. Традиційні стереотипи щодо старіння, старості й людей третього віку, які довгий час панували в суспільстві, зазнають змін. Це пов'язано з соціальними, економічними, технологічними та культурними фракторами. Однією з характерних ознак суспільного 